\title{
A note on style
}

The style used in this book may need some explanation. I have found it more appropriate to use the terms CE (Common Era) and BCE (Before Common $\mathrm{Era}$ ) rather than $\mathrm{BC}$ or $\mathrm{AD}$, but I have not added in $\mathrm{AH}$ (Muslim) years or years in the Jewish calendar.

I have chosen generally to use variants of people's names that, as best we can tell, were those that applied in the lifetime of the individuals concerned, in preference to those used today. This is in part to help distinguish the historical individual from the figure of modern religious faith: the 1st-century CE Jewish religious prophet Yeshua rather than the 21st-century figure of religious worship Jesus. Thus I generally use Yeshua rather than Jesus/Iesous/ Gesù/Isa; Paulos rather than Saint Paul; Muhammad ibn 'Abdullah rather than the Prophet Muhammad; Zarathushtra rather than Zoroaster; and, in the style of his time, Joseph Smith, Jun. Following the styles of the contexts, God may be referred to as male.

What believers in a faith would describe confidently as revelation, outsiders might punctuate as 'revelation'. Here I avoid the extra punctuation. The term applies broadly to the message received or delivered by those who see it derived from the divine. The Mormons' Doctrine and Covenants includes revelations to the founding prophet and some of his successors that relate both to matters of theology and to practical aspects of the development of the Church.

Anachronisms are hard to avoid. The name Mormons would be applied to the Latter-day Saints but was not introduced by them; the followers of the Jesus movement were not called Christians until some years after Yeshua's death. The conquerors from the Arabian Peninsula would probably not have described themselves as Arabs. Today, the largest Zoroastrian community, living in India, call themselves Parsees - Persians.

Terms like Israel, Palestine, Syria and Judah/Judaea have had different meanings at different times. Places often have different names in past and present, and there are differing transliterations from Arabic and other scripts, so where possible I have indicated alternative spellings and names the first time a place is mentioned. 
I have avoided diacritical marks on transliterated names: they add little for the non-specialist reader and the specialist will be aware of the conventionally transliterated form. I have, however, sought to retain the ain (') and hamza (') of Arabic words and names, and used the conventional 'b.' for ibn or ben (son of) in names.

To reduce the overall density of notes, references to the sources for different statements within a single paragraph of the text have in places been combined into a single note. I concede that the secondary materials accessed are biased towards those in English. References to websites were live at time of completion of the manuscript in August 2020. 
Robin Derricourt - 9781526156198 Downloaded from manchesterhive.com at 04/26/2023 10:27:17AM via free access 